\title{
4.1.10 COATINGS FOR INCREASING AND PRESERVING THE BENDING STRENGTH OF GLASS
}

\author{
A. Gier, K. Endres, D. Anschütz, M. Mennig, \\ H. Schmidt
}

\section{INTRODUCTION}

The practical strength of glass with a value of about $100 \mathrm{MPa}$ is approximately 100 times smaller than its theoretical ones [1]. This is due to micro flaws on the glass surface, which amount up to 50.000 on one $\mathrm{cm}^{2}$ [2]. During the handling of glass externals stresses are amplified by these flaws, like clefts, pores or inclusions [3]. The degree of amplification depends on the geometry of the crack tip, which can be strongly influenced by chemical interactions with the surroundings. Depending on the intensity of these external influences, a rather slow crack propagation is observed under subcritical load (static fatigue). However, when the applied tensile stress exceeds a critical value $\left(\mathrm{K}_{\mathrm{ic}}\right.$-factor) the crack grows spontaneously with almost the speed of sound [4,5], leading essentially to the breaking of the glass.

\section{INCREASING THE STRENGTH OF GLASS}

Several different strategies are described in the literature to increase the strength of glasses. A first way is the healing of the damaged surface by mechanical or fire polishing. The surface polishing with strong acids, like $\mathrm{HF}$ or a $\mathrm{HF}-\mathrm{H}_{2} \mathrm{SO}_{4}$ mixture, is also described [6]. A second way is to generate compressive stresses in the glass surface, which have to be overcome by tensile stresses before a resulting tensile load leads to a spontaneous crack growth. This can be obtained by tempering the glass above $\mathrm{T}_{\mathrm{g}}$ followed by a quick cooling of the surface with cold air. This procedure, often used for automotive and architectural glazing, is limited to panes thicker than $3 \mathrm{~mm} \mathrm{[6].} \mathrm{Another} \mathrm{way} \mathrm{to} \mathrm{generate} \mathrm{compressive}$ stress is achieved by ion exchange. For this the glass is dipped in a melted salt, for example $\mathrm{KCl}$, to exchange $\mathrm{Na}^{+}$from the soda lime glass against $\mathrm{K}^{+}$ions. As the radius of the $\mathrm{K}^{+}$ions is $30 \%$ bigger than the radius of $\mathrm{Na}^{+}$ions, a compres- 
sive stress is therefore obtained in a $60-150 \mu \mathrm{m}$ thick surface layer after cooling down the glass from the ion-exchange temperature (below $\mathrm{T}_{\mathrm{g}}$ ) down to room temperature [7]. This process requires a long time (up to $24 \mathrm{~h}$ ) processing, is of high cost and is also limited to glasses at least 2 to $3 \mathrm{~mm}$ thick. Therefore, glass strengthening by ion exchange is limited to special glass application like watch glasses or glass moulds for plastic eye glass fabrication.

An alternative way to increase the strength of glass is to coat this surface with sol-gel derived glass-like layers. Uhlmann and Fabes predicted a model flaw filling by $\mathrm{SiO}_{2}$ sol-gel coatings on silica glass and Schmidt could show, that the strength of soda-lime glass could be increased up to a factor of 4 by depositing different multiple glass-like coatings. A detailed review of the state-of-the-art for the healing of micro cracks by chemical treatments and coatings is given in [11].

Recently, a new coating approach has been proposed, which combines two different strength increasing effects. First a coating derived from an TEOS (tetraethoxysilane) sol is deposited to get a thickness of about $100 \mathrm{~nm}$ after thermal densification at $500{ }^{\circ} \mathrm{C}$. Investigations of the glass strength with the double ring bending test (DIN 52 292) [12] and an evaluation by the Weibull statistics [13] showed that it is possible to fill at least partially the flaws and to enhance the strength [11]. If the sol reaches the crack tips it can cause an increase of bending strength by rounding the crack tips. A comparison between uncoated and a TEOS coated glass shows a nearly parallel shift of the Weibull plot to higher strength values. From these results it could be concluded, that not only smaller cracks but also larger defects are influenced by the silica coating. Due to the increase of the strength, a blunting of the crack tips can be assumed. According to the strategy to generate compressive stresses inside a region near the surface of the glasses, which have to be exceeded by external tensile stresses before a resulting tensile load can attack the crack trip, a second nanoparticulate methylmodified $\mathrm{SiO}_{2}$ coating (MTKS) [14,15] was used to increase the bending strength. The tetraethoxysilane, methyltriethoxysilane and silica nanoparticles had a thickness of about $2 \mu \mathrm{m}$ after thermal densification at $500^{\circ} \mathrm{C}$. Figure 1 shows the evaluation of the double ring bending tests for the different coating types and the combination of a thin and a thick $\mathrm{SiO}_{2}$ layer.

Detailed investigations [11] showed that the MTKS sol is able to cover the cracks completely but cannot reach the bottom of the cracks because of its high viscosity and sol structure. Therefore, the strength of the coated glass is caused by the strength of the MTKS coating, which does not close the crack but clamps them. A TEOS coating applied underneath has no influence on this because the increased bending strength, caused by the MTKS clamp, is larger than the increase of strength by the silica (TEOS) coating. This means that by applying a load which breaks the MTKS clamp, the TEOS coating should fail as well with an immediate crack spreading. This hypothesis explains why an increase of the coating thickness cannot result in a further increase of the bending strength, because the strength of the MTKS coating is independent from the thickness above a definite level. 


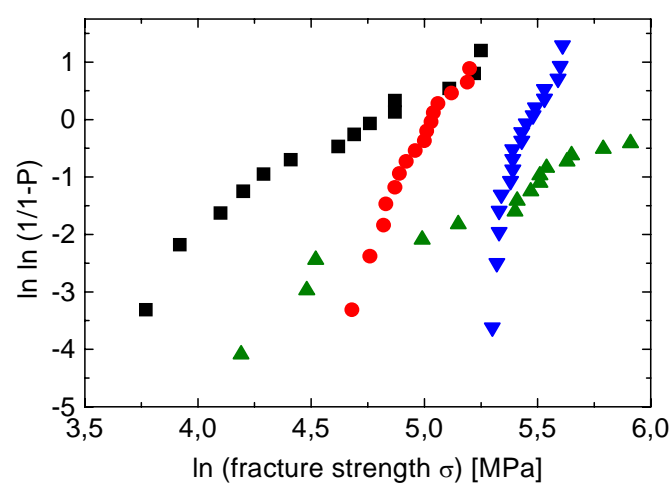

Figure 1. Weibull plot of coated and uncoated glass.

- uncoated: $\sigma_{0}=125 \mathrm{MPa},(106-147 \mathrm{MPa}), \mathrm{m}=2,2(1,6-2,7)$

- $\mathrm{SiO}_{2}$ (TEOS), $\left.100 \mathrm{~nm}\right): \sigma_{0}=155 \mathrm{MPa},(148-163 \mathrm{MPa}), \mathrm{m}=7,4(5,5-9,0)$

$\Delta \mathrm{SiO}_{2}$ (MTKS, $\left.2 \mu \mathrm{m}\right): \sigma_{0}=249 \mathrm{MPa},(218-284 \mathrm{MPa}), \mathrm{m}=2,7(2,0-3,3)$

$\nabla \mathrm{SiO}_{2}$ double coated (TEOS + MTKS): $\sigma_{0}=245 \mathrm{MPa},(236-254 \mathrm{MPa})$, $\mathrm{m}=10(7,6-12)$

Further, the smaller Weibull modulus of the MTKS coating in relation to that obtained for a damaged uncoated glass can be understood by assuming that the clamping effect is smaller for a very large damage than for a smaller one because the probability of a defect rises with the dimension of the clamp. Figure 2 shows the function of each of the two sols and the combination of them.

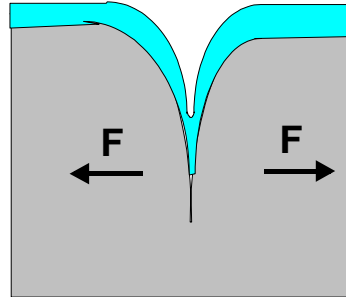

TEOS coating

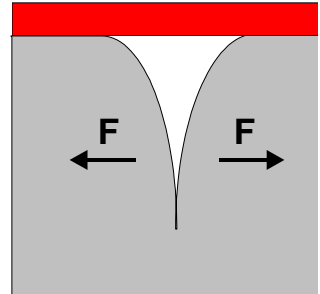

MTKS coating

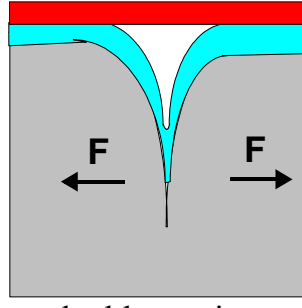

double coating $(\mathrm{TEOS}+\mathrm{MTKS})$

Figure 2. Functions of the developed coatings.

As can be seen in the figure, the TEOS coating is able to fill the tips of the cracks and to round them. The MTKS cannot reach the bottom of the crack but covers it and clamps it. The combination of both leads to a maximum increase of the strength. This combination of a TEOS / MTKS coating leads to an increase of the bending strength of glass by a factor 2 . 


\section{PRESERVING THE STRENGTH OF GLASS}

Such inorganic glass-like coatings are however not suitable for the protection of the glass surface against mechanical loads [11]. The strength increasing effect of different $\mathrm{SiO}_{2}$ coatings on float glass, as discussed above, can be completely eliminated by a sand trickling test [16]. Therefore defects generated in the coatings can easily propagate as micro flaws into the glass substrate, since there is a perfect chemical bonding of the coating with the substrate and both have similar elastic moduli. Several strength preserving coatings based on organic polymers have been developed, but they all lead to problems at the recycling process because of their high amount of carbon. Another general approach is to protect the glass surface from damage by hard ceramic $\left(\mathrm{Al}_{2} \mathrm{O}_{3}, \mathrm{ZrO}_{2}\right)$ coatings [17]. Such coatings provide efficient protection of the glass surfaces for only rather small indenter loads, as the coatings are usually very thin $(<<1 \mu \mathrm{m})$ but break under high indenter loads like "thin ice on water". A detailed review of the state-of-theart for strength preserving coatings is given in [18].

Recently, an elastic organic-inorganic strength preserving coating was developed to protect reliably bottles against the mechanical loads of a filling line [19]. Figure 3 shows the difference in the function of a hard strength increasing glasslike coating and an elastic strength preserving coating.

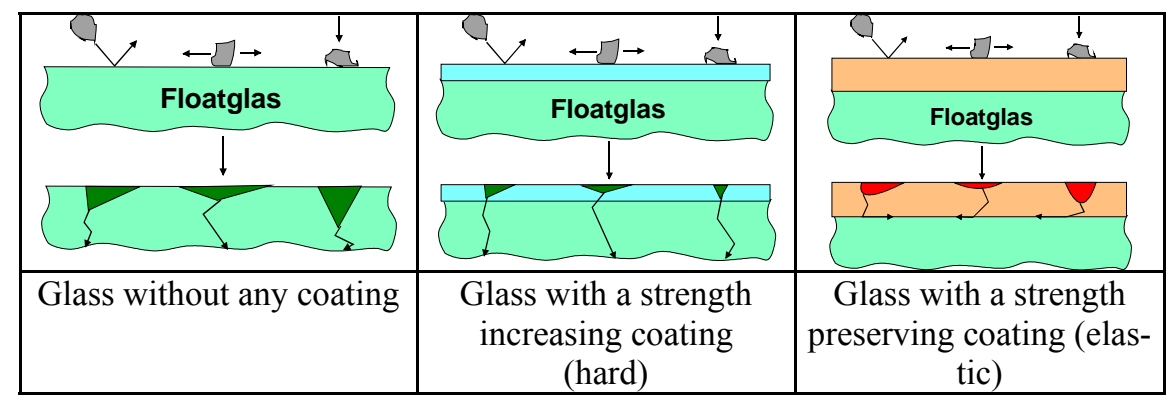

Figure 3. Glass coated with different layers under mechanical loads.

The glass surface (left) is damaged by different abrasive and indenter loads, which automatically lead to a strong decrease in bending strength. In the case of glasses coated with a strength increasing glass-like layer (middle), the coating is damaged by different mechanical attacks as well and the generated defects propagate into the glass substrate. In the case of an organic-inorganic, strength preserving coating (right) the propagation of cracks into the glass surface is prohibited due to insufficient covalent chemical bonding to the glass and a much smaller elastic modulus. The developed coating preserves fully the surface of float glass against the damage caused by $500 \mathrm{~g}$ sand in a sand falling test and bottles against a 2 minutes wet line simulation $[18,19]$. As the coatings are only $7 \mu \mathrm{m}$ thick and have a low carbon content, the recycling of such coated bottles 
do not cause any technical problems. The coating can be applied by several methods, like dip- or spray coating on cold and warm $\left(80^{\circ} \mathrm{C}\right)$ glass bottles.

\section{CONCLUSION}

Sol-gel glass-like coatings can effectively increase the strength of glass substrates. This was demonstrated by a 2 layer combination, the first one made from a TEOS sol being able to fill the tips of the cracks and to round them, the second one made from a MTKS sol covering and clamping the cracks. These coatings can be however damaged by mechanical loadings so that the benefits are easily lost. Sol-gel elastic organic-inorganic strength preserving coatings have been developed for float glass substrates withstanding a $500 \mathrm{~g}$ sand falling test and two minutes wet line bottles filling equipment.

\section{REFERENCES}

1. H. Müller-Simon, J. Wagner, A. Lenhardt, Practical strength of glass containers Part. 1: Influence of the type of defects, Glastechn. Ber. Glass Sci. Technol., 67 (5), 134 (1994)

2. F. M. Ernsberger, Advances in glass technology, New York, Plenum Press 511 (1962)

3. A. Griffith, Phil. Trans., A221, 163 (1920)

4. O. L. Anderson, T. L. Preiser, Role of environment in stress corrosion cracking in silicate glasses, J. Am. Ceram. Soc., 61, 534 (1978)

5. S. M. Wiederhorn, Influence of water vapor on crack propagation in solda-lime glass, J. Am. Soc., 50, 407 (1967)

6. H. Richter, Festigkeit anorganischer, nichtmetallischer Werkstoffe, HVG Fortbildungskurs, Festigkeit von Glas, 1 (1987)

7. H. Scholze, Glas-Natur, Struktur und Eigenschaften, 3. Auflage, Springer Verlag Berlin (1988)

8. B. D. Fabes, D. R. Uhlmann, Strengthening of glass by sol-gel coatings, J. Am. Ceram. Soc., 73, 978 (1990)

9. H. Schmidt, Presentation at Soc. of Glass Tech. Symp. on Glass Strength, Harrowgate (1988)

10. P. Strehlow, H. Schmidt, Verfahren zur Herstellung von Gläsern mit erhöhter Bruchfestigkeit, EP 0294830 B1

11. A. Gier, M. Amlung, K. Endres, M. Mennig, H. Schmidt, Untersuchungen zur Festigkeit von Glas: Verhalten und Heilen von Mikrorissen unter gezielten chemischen, atmosphärischen und mechanischen Bedingungen, AiF Abschlussbericht, Nr. 10651, Institut für Neue Materialien, Saarbrücken (1998)

12. DIN 52 292, T 1 (April1984): Bestimmung der Biegebruchfestigkeit: Doppelringbiegeversuch an plattenförmigen Proben mit kleiner Probenfläche. Berlin DIN 1984

13. W. A. Weibull, A statistical distribution of wide applicability, J. Appl. Mech., 18, 293 (1951)

14. M. Mennig, G. Jonschker, H. Schmidt, Sol-gel derived thick coatings and their thermochemical and optical properties, in: Spie Proc. "Sol-Gel Optics II", vol. 1758, 125 (1992)

15. M. Mennig, G. Jonschker, H. Schmidt, Verfahren zur Herstellung von Glas mit verbesserter Langzeitstandfestigkeit bei erhöhten Temperaturen, DE 4217432 A1

16. DIN 52348 (Februar 1985) Prüfung von Glas und Kunststoff. Verschleißprüfung, Sandrieselverfahren. Berlin DIN 1985

17. R. Hauk, G.H. Frischat, K. Ruppert, Sol-gel preparation of scratch resistant $\mathrm{Al}_{2} \mathrm{O}_{3}$ coatings on float glass, in: Glastechnische Berichte. Glass Science and Technology, 72, 386 (1999) 
242 Sol-gel technologies for glass producers and users

18. A. Gier, D. Anschütz, M. Mennig, H. Schmidt, Untersuchungen zur Festigkeit von Glas: Festigkeitserhaltende und festigkeitserhöhende Schichten auf Glas, AiF Abschlußbericht, Nr. 11685N, Institut für Neue Materialien, Saarbrücken, 2000

19. M. Mennig, A. Gier, D. Anschütz, H. Schmidt, Development of organic-inorganic coatings for strength-preserving of glass bottles, Glastechnische Berichte, Glass Science and Technology, 74, $217(2001)$ 